\title{
The Ability of Explaining and Predicting of Economic Value Added (EVA) versus Net Income (NI), Residual Income (RI) \& Free Cash Flow (FCF) in Tehran Stock Exchange (TSE)
}

\author{
Akbar Parvaei ${ }^{1} \&$ Soran Farhadi ${ }^{1}$ \\ ${ }^{1}$ Faculty of Management, University of Tehran, Tehran, Iran \\ Correspondence: Akbar Parvaei, Faculty of Management, University of Tehran, Tehran, Iran. Tel: \\ 98-935-645-6089. E-mail: parvaei.a@gmail.com
}

Received: January 26, 2012

Accepted: March 8, $2012 \quad$ Online Published: January 10, 2013

doi:10.5539/ijef.v5n2p67

URL: http://dx.doi.org/10.5539/ijef.v5n2p67

\begin{abstract}
Current research examines the main performance measures (Net income (NI), residual income (RI), economic value added (EVA) \& free cash flow (FCF)) of firm and management to find out whether EVA works better than other performance measures in terms of evaluating the firm's performance. Then we examine the predictability of Economic Value Added for future performance. For doing this, we employ both relevant information content and incremental information content of measures. Our results generally show that EVA is the best measure for evaluating the performance of firm and management among other measures. Furthermore, we find that EVA has low predictability for performance and FCF has slightly superior predictability compared to other measures.
\end{abstract}

Keywords: net income, residual income, economic value added, free cash flow, relevant information content, incremental information content

\section{Introduction}

Choosing the best performance measure for evaluating the firm and management has always been considered as a crucial issue. As a result of time constraints and specialization of activities, the role of management and its importance has emerged in corporations formed centuries ago. In spite of all advantages, major challenges have arisen following the emergence of managers that indicate the aspect of agency theory, known as separation of interests between managers and ownerships. Business owners hire the managers to administer the firm's activities and as result this leads to agency relationships. It is evident that the goals of managers and business owners are hardly ever compatible because managers look for extensive economic benefits (such as compensation, prestige, etc.), while the owners are interested in maximizing their investments return and price of stocks. Jensen (1986) proposes that managers tend to squander the free cash flow in the firms, whenever the objectives of shareholders and managers differ. Due to this interest asymmetry between owners and managers, researchers have looked for the best performance measure to evaluating the ability of managers to conclude their tasks. Therefore, the current paper is going to present the most optimal performance measure of firm and management. Nowadays, many performance measures are presented that the three most important ones are net income, cash flows and economic income.

Net income (NI) has been considered as a performance measure since many years. This scenario continued until extensive researches finally showed that accounting income is unsatisfactory concept for performance and profitability measurement. The reason for this claim is that accounting income does not consider the opportunity cost of the capital employed (Dearden 1972 and Anthony 1973). They believed that residual income (RI) is a better measure for evaluation of firms and managers compared to the accounting income.

As another performance measure, Economic value added (EVA) is one of the newest techniques used for evaluating performance. The first evidence about economic value added and market value added was documented by Stewart (1991). Stewart surveyed 613 American firms and found that EVA approximately explains $97 \%$ of market value added changes. Moreover, he justified that EVA is more optimal performance measure than other measures.

The main point inferred from EVA is that firms generate positive EVA whenever the investment return rate overcomes Cost of Capital rate. In the other research, Stewart (1993) investigated accounting and economic 
measures to find out which one works more effectively. Results of his research showed that EVA has superiority to explain the stock return versus other accounting measures such as return on equity (ROE), earnings per share (EPS) and cash changes. Consequently these results are led to use of EVA instead of other measures in many firms. EVA as management control system uses for calculating performance of firms (Desai et al., 2006) and it also helps the management to improve the performance of firm by paying attention to capital costs and investment returns.

Free cash flow (FCF) as another performance measure indicates cash flows that firms retain after capital maintenance and developing assets. Mulford and comiskey (2005) believe that "the term 'free' refers to an absence of a superior claim; it is cash flow that is available for use with no strings attached. Spending it will not affect the firm's ability to generate more."

From decision making point of view, cash flow plays significant role for evaluating firm's position compared to income statement which is one of the noisiest statements that may mislead investors. For example, the firm can show high net income in its financial statements, while it is unable to pay back its liabilities. Fabozzi and Peterson (2003) believe that "From a shareholder's perspective, free cash flow may be an appropriate measure because this represents the cash flow that is reinvested in the company.

As a result, the current paper is going to examine the main performance measures (Net income (NI), residual income (RI), economic value added (EVA) \& free cash flow (FCF)) of firm and management. First, we will examine whether EVA works better than other performance measures in terms of evaluating the firm's performance. Then we will determine which measure has more predictability power in order to find out whether EVA has the highest predictability power among other variables. For this pupose, we employ measures' relevant information content as well as incremental information content. Our results generally show that EVA is the best measure for evaluating the performance of firm and management among others. Furthermore, we find that EVA has low performance predictability power and FCF has slightly superior predictability power in comparison with other measures. The details will be presented in the next parts.

\section{Literature Review}

Specifying a rational performance measure for firms has turned out as a crucial issue for researchers. In time, the gradual growth of this incentive was accompanied by the emergence of new measures of firm and management evaluation. In different decades, researches centered around different measures and in 1990s they were mostly centered on EVA as one the most recent measures. After Stewart (1991) claimed; EVA is the best performance measure, many researches have been done to verify its accuracy. Lehn and Makhija (1996) examined the American firms to evaluate the relationship between performance measures such as EVA, market value added (MVA), return to equity (ROE), return to assets (ROA) and return to sales (ROS), and the stock return. Results showed that all the mentioned performance measures have positive relationship with the stock return. Furthermore, they argued that there is significant association between stock return and EVA among other measures. Similarly, there are many researches that evaluated the relationship between EVA and the stock return and their results showed the superiority of EVA, e.g. (Uyemura et al. 1996, Hall 1998, Holiana et al. 2011 and Haddad 2012).

Some researchers examined different measures. For example, Worthington and West (2004) investigated the accounting measures (earnings before extraordinary items (ERN) and net cash flows from operations (NCF)) and economic measures (residual income (RI) and economic value added (EVA)) to find out which variable has the largest relative information content. Their research was on 110 Australian companies over the period 1992-1998 and they showed that EVA has the largest relative information content among others.

Some papers also evaluated the relationship between performance measures and market value added (MVA). For example, Fingan (1991) demonstrated that there is significant association between MVA and EVA comparing to other performance measures such as earning per share, cash flows, capital growth and return on equity.

In EVA literature, some researchers studied about adoption of EVA and firm's risk. Prakash et al. (2003) examined the impact of adoption of EVA on the risk characteristics of the firms. They employed the event study approach and their sample included 48 firms that adopted EVA between 1987 and 1996. Their results showed that in the post adoption period, for majority of the firms systematic risk decreases, but unsystematic risk and total risk increase. Their justification was that firms that adopt EVA, simultaneously reach higher stock return and this leads to high levels of risk for them. As other research about adoption of EVA by firms, Hamilton et al. (2009) investigated that whether firms that adopt EVA comparing to non-adopters are faced with higher performance. They reported that EVA adopters show less negative performance than non-adopters. They also found that adopter performance improves in a positive direction, while non-adopters experience a performance decline too. They claimed that EVA creates some benefit for adopters. 
Some papers also examined predictability of EVA and other measures. Machuga et al. (2002) studied information content of EVA, net income, cash flows and stock return for predicting earning per share (EPS). They reported that EVA has the greatest ability for predicting EPS among others. Movassagh et al. (2011) reached similar conclusions.

The evidence of paradox about EVA and the stock return was documented by Fu et al. (2011). They formed 10 portfolios and ranked from the highest positive EVA firms to most negative EVA firms. They reported that returns of negative EVA firms are higher than for positive EVA firms. They argued that this situation arise because of investor's confidence in future expectations for these firms.

In contrast, in EVA literature there are some papers that documented that EVA has no superiority among other measures and rejected the Stewart's claims. Tsuji (2006) examined to find out which valuation measures including EVA, cash flow, operating income and profit after tax can indicate market value of the firms effectively. His sample size included 562 Japanese listed firms and the sample period was the 21 years from 1982 through to 2002. The results of his research exhibited that firm's market values have stronger linkages with cash flow and other earnings measures than EVA. O'Byrne (1996) investigated the relationship between EVA, earnings measures and free cash flow (FCF), and the stock return. He reported that earnings measures unlike EVA have significant association with the stock return. Similarly there are many papers that documented the superiority of net income among other measures, e.g. (Biddle et al. 1997, Chen and Dodd 2001, Kramer and peters 2002, Fernandez 2003 and Shubita 2010).

Some papers also concluded that return to assets (ROA) has the superiority among others. For example, Chen and Dodd (1996) examined the relationship between EVA, EPS, ROA and ROE, and the stock return. They reported that ROA unlike the other measures has significant association with the stock return. ArabSalehi and Mahmoodi (2011) reached similar conclusions.

Some researchers investigated EVA from valuation aspect. For example Shrieves and Wachowicz (2001) examined EVA, free cash flow (FCF) and net present value (NPV) to show that which measure has greater power from valuation aspect. They documented that all the measures have same power for valuating.

As result, there is no agreement among the researches about the best performance measures but from quantitative point of view, Sharma and Kumar (2010) argue that there are less numbers of studies that do not show the superiority of EVA among other measures in developed country.

\section{Sample and Variables}

\subsection{Sample Selection}

The sample used for this research includes 80 Iranian firms that listed in Tehran stock exchange (TSE) over the years 2005 to 2009. For better evaluation, firms with equal time periods had been selected. In addition, firms without transactions in periods of more than two months have been excluded. Furthermore, banks and financial companies were omitted.

\subsection{Variables}

\subsubsection{Dependent Variable}

Dependent variable in this research is annual stock return. The variable is directly acquired from Tehran stock exchange (TSE).

\subsubsection{Independent Variables}

Economic value added (EVA) is calculated in this way:

$$
\text { EVA }=\text { Adj NOPAT }-(\text { Capital Employed } \times \text { WACC })
$$

NOPAT $=$ Net operating profit after taxes

WACC $=$ weighted average cost of capital

$$
\text { Adj NOPAT }=\text { Operating Profit } \times(1-\text { Tax Rate })+\text { Provisions }
$$

Provisions $=$ Advertising Expense $+\mathrm{R} \& \mathrm{D}$ Expense + Bad debt

$$
W A C C=w_{e} k_{e}+w_{d} k_{d}(1-\operatorname{Tax})
$$

$\mathrm{w}_{\mathrm{d}}, \mathrm{w}_{\mathrm{e}}=$ debt' weight and common stock' weight, respectively

$k_{d}, k_{e}=$ Cost of debt and cost of equity, respectively 
Cost of debt is obtained from annual government's reports. Capital assets pricing model (CAPM) is employed to calculate the cost of equity. We calculate Beta individually for each firm and put them in CAPM model to find out the cost of equity. This approach was used by Teker et al. (2011) and Fiordelisi (2007).

$$
K_{e}=K_{r f}+\beta\left(K_{m}-K_{r f}\right)
$$

$\mathrm{K}_{\mathrm{RF}}=$ Treasury Bills Rate of Return of Central Bank of Iran

$\mathrm{K}_{\mathrm{M}}=$ Market Index Rate of Return of Tehran Stock Exchange

$\beta=$ market risk for the stock of each firm

$$
\beta_{c}=\left(\operatorname{Cov}\left(R_{m}, R_{c}\right)\right) /\left(\operatorname{var}\left(R_{c}\right)\right)
$$

$\mathrm{R}_{\mathrm{m}}=$ periodic return of index

$\mathrm{R}_{\mathrm{c}}=$ periodic stock return of firm $\mathrm{c}$

Free cash flow (FCF) is calculated in this way:

$$
F C F F=E B I T(1-T)+\text { Depreciation - Capital expenditures - Increase in NWC }
$$

$\mathrm{FCFF}=$ free cash flow for the firm

EBIT $=$ earnings before interest and taxes

$\mathrm{NWC}=$ net working capital

Residual income (RI) is calculated in this way:

$$
R I=N O P A T_{t}-\left(\text { Capital Employed }_{t-1} \times W A C C_{t}\right)
$$

Net income (NI) is directly obtained from financial statement of the firms for different periods.

Table 1 presents descriptive statistics of dependent and independent variables. As shown, maximum and minimum amounts of mean respectively belong to RI (1.28) and $\triangle \mathrm{EVA}(0.31)$. We employ Jarque-bera test for checking the normality of variables. The results of the test show that all variables follow the normal distribution. We also use Variance Inflation Factors method (VIFs) to measuring the level of collinearity in models. The result of VIFs test reveals that VIF of variables are less than 10 which indicates that collinearity is not significant in our research.

Table 1. Descriptive statistics

\begin{tabular}{lcccccccccc}
\hline & $\mathbf{R}_{\mathbf{t}}$ & $\mathbf{E V A}$ & $\mathbf{N I}$ & $\mathbf{R I}$ & $\mathbf{F C F}$ & $\mathbf{R}_{\mathbf{t + 1}}$ & $\boldsymbol{\Delta E V A}$ & $\boldsymbol{\Delta N I}$ & $\Delta \mathbf{R I}$ & $\boldsymbol{\Delta} \mathbf{F C F}$ \\
\hline Mean & 0.28 & 0.00 & 0.05 & 1.29 & 0.09 & 0.30 & -0.32 & -0.11 & -0.03 & -0.03 \\
Median & 0.19 & 0.25 & 0.16 & 1.15 & 0.11 & 0.20 & -0.06 & 0.00 & 0.08 & 0.02 \\
Maximum & 5.02 & 1.26 & 1.29 & 5.84 & 3.77 & 5.02 & 1.60 & 1.23 & 1.84 & 3.28 \\
Minimum & -0.64 & -5.58 & -6.08 & 0.08 & -10.48 & -0.64 & -6.45 & -1.02 & -9.69 & -2.25 \\
Std. Dev. & 0.55 & 0.91 & 0.51 & 0.61 & 7.92 & 0.54 & 0.85 & 0.77 & 1.26 & 3.58 \\
\hline
\end{tabular}

\section{Hypothesis}

This research includes 8 hypotheses that classify in 4 categories.

Hypothesis 1: A. EVA has the largest relative information content with the current stock return among other measures.

B. EVA has the largest incremental information content with the current stock return among other measures.

Hypothesis 2: A. EVA changes ( $\triangle \mathrm{EVA})$ have the largest relative information content with the current stock return among changes of other measures.

B. EVA changes $(\triangle \mathrm{EVA})$ have the largest incremental information content with the current stock return among changes of other measures.

Hypothesis 3: A. EVA has the largest relative information content with the future stock return among other measures.

B. EVA has the largest incremental information content with the future stock return among other measures.

Hypothesis 4: A. EVA changes ( $\triangle \mathrm{EVA})$ have the largest relative information content with the future stock return among changes of other measures. 
B. EVA changes $(\triangle \mathrm{EVA})$ have the largest incremental information content with the future stock return among changes of other measures.

\section{Methodology}

In this paper, we employ pooled regression method for testing the hypothesis. Baltagi (2008) argued that pooling data has some advantages such as giving a richer source of variation which allows for more efficient estimation of the parameters. With additional informative data, one can get more reliable estimates and test more sophisticated behavioral models with less restrictive assumptions. Also, another advantage is their ability to control for individual heterogeneity. There are different methods of pooling panel data including the fixed effects and the random effects model. Fixed effects are used when we want to consider all regression coefficients restrict to be the same across all cross sections and random effects are used when we think that the unobserved effect is uncorrelated with the explanatory variables. We use F-test and Hausman-test to identify which method should be considered for models of this research. According to the results, fixed effects pooled model is more appropriate for our models.

For determining which measure has the greatest relative information content, we employ one variable regression for each measure. Then, we observe adjusted $\mathrm{R}^{2}$ of all regression models. Whichever that has greater adjusted $\mathrm{R}^{2}$, has greater relative information content too. Many researchers employed this approach in their papers, e.g. (Biddle et al. 1997 and Holiana et al. 2011).

Our approach for investigating the incremental information content is that we first pair variables together in a multiple regressions, and then we deduct adjusted $\mathrm{R}^{2}$ of multiple regressions from adjusted $\mathrm{R}^{2}$ of related one variable regressions, the difference indicates the incremental information content. Worthington and West (2004) apply this approach in their research.

\section{Empirical Results}

Hypothesis 1: Results of the investigating hypothesis 1 are presented in table 2. As shown, this table consists of 3 parts. Part A shows the data of regression models and part B exhibits the results of relative information content and finally results of incremental information content are presented in part C. part A shows data such as Estimated Coefficient, $\mathrm{t}-$-statistics, Standard Errors, $\mathrm{F}$-statistic and adjusted $\mathrm{R}^{2}$ related to each models. Every four proceeding models contain one variable regression for each independent variable (EVA, NI, RI and FCF) and the next 6 models include the multiple regressions for paired variables. In every one variable regression, all independent variables have a positive relationship with the current stock return and EVA has the greatest Estimated Coefficient among others. Minimum Standard Errors for all one variable regressions belong to FCF. In pairwise regressions there is also positive relationship between independent variable and the stock return and again EVA has the greatest Estimated Coefficient among others.

As mentioned, part B in table 2 shows the degree of relative information content for each independent variable. The greatest relative information content belongs to EVA (0.27), NI (0.14), RI (0.11) and FCF (0.09), respectively.

Therefore, Hypothesis 1(A) is accepted. In other words, EVA has the largest relative information content with the current stock return among others. Other variables have relatively equal relative information content. This result supports the claims made by Stewart that EVA is a better measure for explaining the stock returns among other accounting based performance measures. Lehn and Makhija (1996) and Haddad (2012) reached similar conclusions.

Part $\mathrm{C}$ in table 2 exhibits the results of incremental information content. As mentioned before, for calculating the incremental information content, first we obtain the adjusted $\mathrm{R}^{2}$ from pairwise regression models and then deduct them from related adjusted $\mathrm{R}^{2}$ of every one variable regression. For example, for obtaining (EVA-NI), we deduct the adjusted $\mathrm{R}^{2}$ of (EVA, NI) from adjusted $\mathrm{R}^{2}$ of $(\mathrm{NI})$, that is, $29 \%-13 \%=16 \%$.

As shown in table 2, EVA has the greatest incremental information content among other measures. It means that Hypothesis 1(B) is accepted too. The incremental information content of NI and RI are almost the same. Furthermore, FCF doesn't have any incremental information content. Worthington and West (2004) and ArabSalehi and Mahmoodi (2011) reached similar conclusions. 
Table 2. This table contains data about regression models

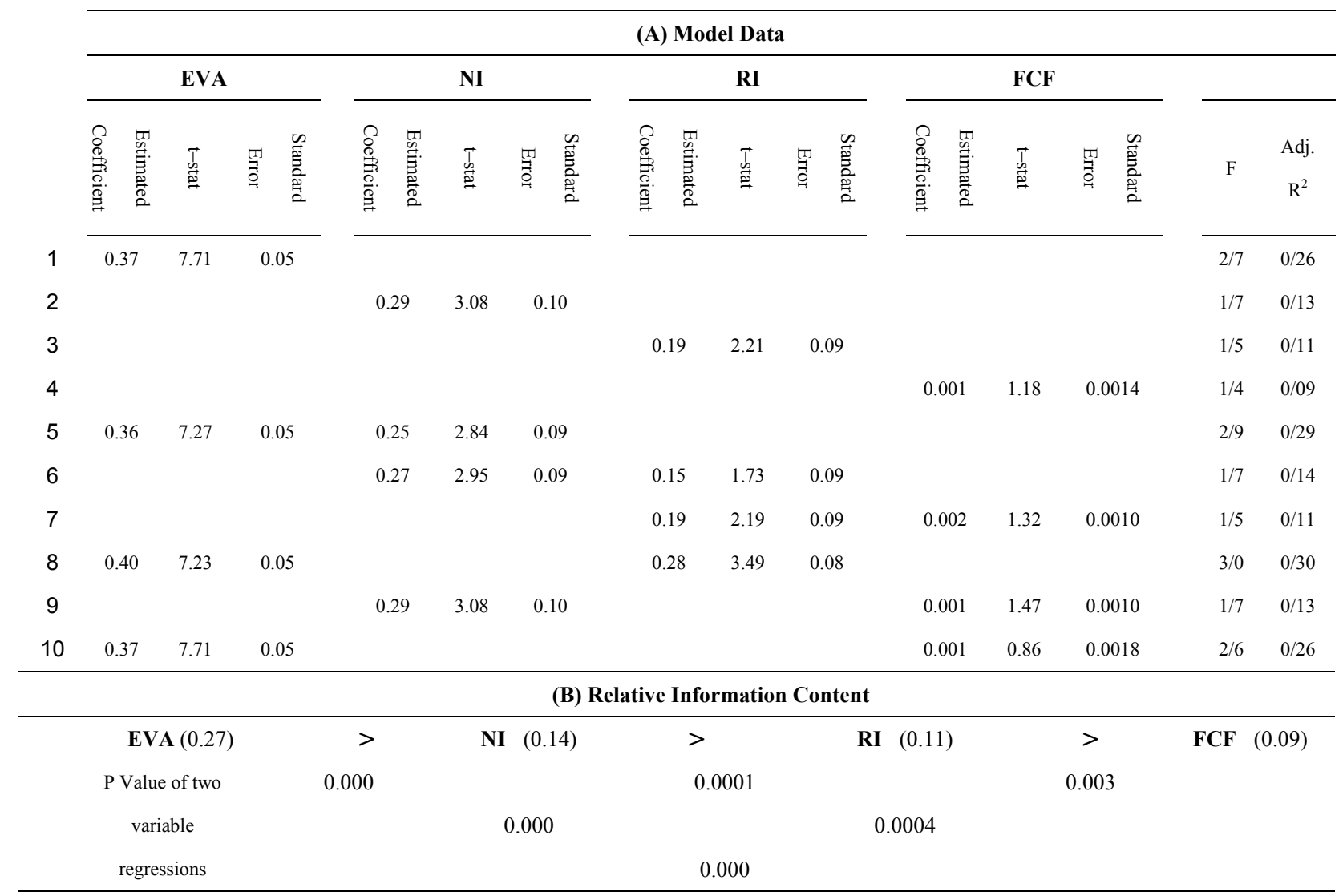

(C) Incremental Information Content

\begin{tabular}{|c|c|c|c|c|c|c|c|c|c|c|c|}
\hline $\begin{array}{l}\text { Ty } \\
\text { 20 } \\
\underline{2}\end{array}$ & 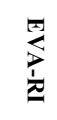 & 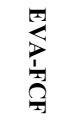 & $\begin{array}{l}\frac{2}{1} \\
\frac{1}{2} \\
\frac{1}{2}\end{array}$ & $\underset{\frac{Z}{2}}{\frac{Z}{2}}$ & $\frac{z}{\frac{Z}{1}}$ & $\frac{\pi}{\frac{\pi}{\pi}}$ & $\frac{\pi}{\underline{\pi}}$ & $\frac{\pi}{\pi}$ & 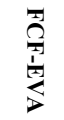 & $\begin{array}{l}\mathbf{x} \\
\stackrel{7}{7} \\
\underline{1}\end{array}$ & 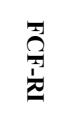 \\
\hline 0.16 & 0.19 & 0.17 & 0.03 & 0.03 & 0.04 & 0.04 & 0.01 & 0.02 & 0.00 & 0.00 & 0.00 \\
\hline
\end{tabular}

significant at the 5 percent level

Notes: There are 10 regression models that four first of them are one variable regressions and the rest of them are two variable regressions. The dependent variable is current stock return and the independent variables are economic value added (EVA), net income (NI), residual income (RI) and free cash flow (FCF).

Hypothesis 2: Results of the investigating hypothesis 2 are exhibited in table 3. Part A shows Estimated Coefficient, t-statistics and Standard Errors related to each models. Four first models include one variable regressions for each independent variable $(\triangle \mathrm{EVA}, \Delta \mathrm{NI}, \Delta \mathrm{RI}$ and $\triangle \mathrm{FCF})$ and the next 6 models contain the multiple regressions for paired independent variables. In right side of table 3, F-statistic and adjusted R2 of models are shown. In every one variable regression, all independent variables have a positive relationship with the current stock return and EVA changes have the greatest Estimated Coefficient among others. Minimum Standard Errors for all one variable regression belong to $\triangle \mathrm{FCF}, \triangle \mathrm{RI}, \Delta \mathrm{NI}$ and $\triangle \mathrm{EVA}$, respectively. In pairwise regressions, there is positive and significant relationship between $\triangle \mathrm{EVA}$ and the stock return.

Part $\mathrm{B}$ in table 3 shows the results of relative information content for each independent variable. The greatest relative information content is related to $\Delta \mathrm{EVA}(0.22), \Delta \mathrm{NI}(0.101), \Delta \mathrm{FCF}(0.1)$ and $\Delta \mathrm{RI}(0.09)$, respectively. As a result, our claim that $\triangle \mathrm{EVA}$ has the largest relative information content with the current stock return among other measures, are accepted. Other variables have relatively equal relative information content. Similarly, O'Byrne (1996) examined the relationship between changes of EVA, earnings measures and free cash flow (FCF), and the stock return and he revealed that changes of EVA have significant association with the stock return.

Part $\mathrm{C}$ in table 3 shows the results of incremental information content. As shown in table 3, the incremental information content of $\Delta \mathrm{NI}, \triangle \mathrm{RI}$ and $\triangle \mathrm{FCF}$ are close to zero, while $\triangle \mathrm{EVA}$ has great incremental information 
content. It shows that Hypothesis 2 (B) is accepted. This result accommodate with result of Worthington and West (2004) research. They showed that EVA changes have the greatest incremental information content among other measures such as earnings before extraordinary items, net cash flows from operations and residual income.

Table 3. This table contains data about regression models

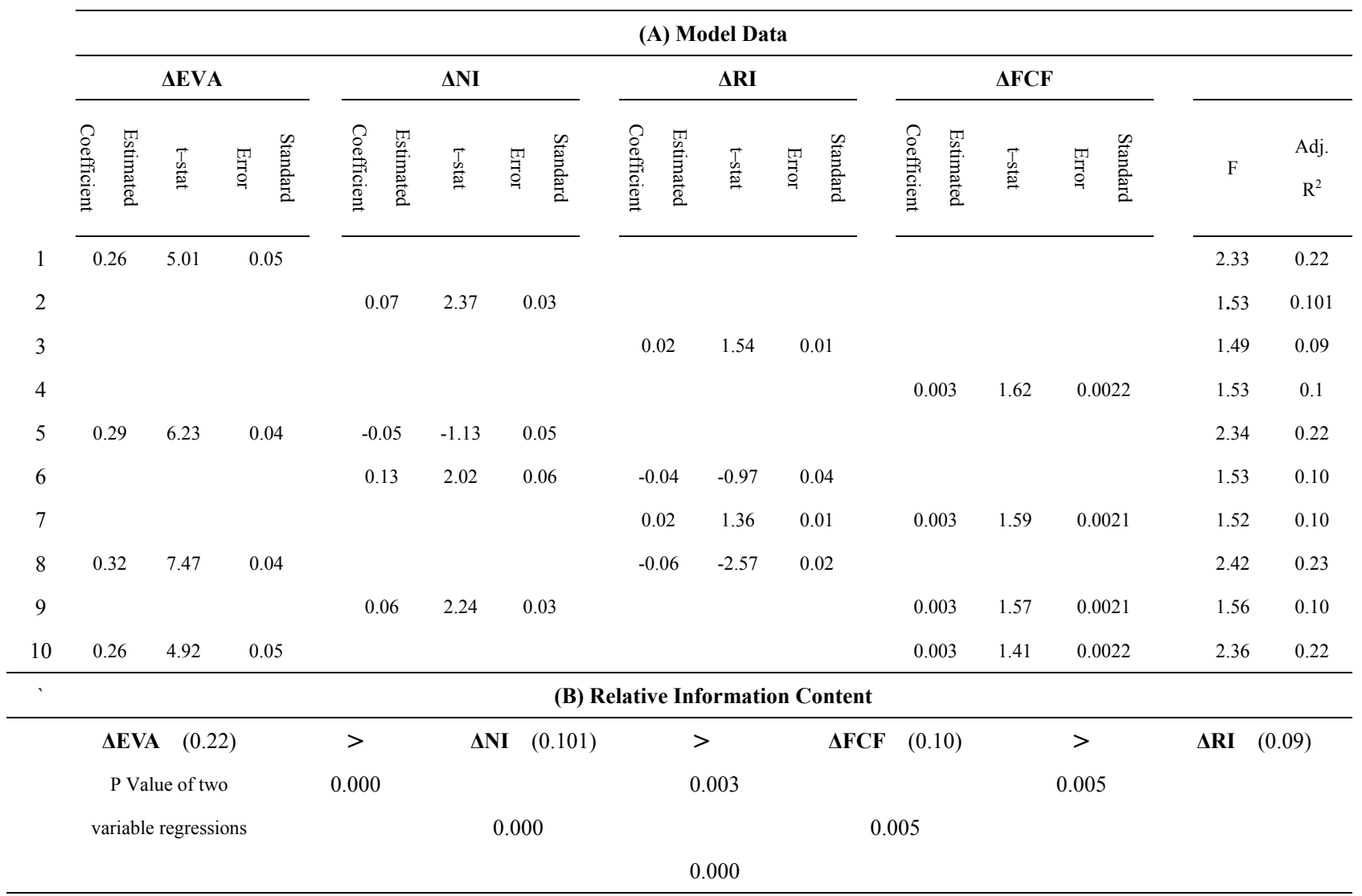

(C) Incremental Information Content

\begin{tabular}{|c|c|c|c|c|c|c|c|c|c|c|c|}
\hline 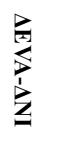 & 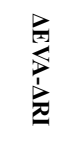 & 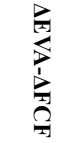 & $\frac{\vec{z}}{\hat{z}}$ & $\begin{array}{l}\underset{z}{\mathbf{z}} \\
\stackrel{2}{\mathbf{z}} \\
\underline{\mathbf{z}}\end{array}$ & 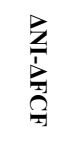 & $\begin{array}{l}\frac{\lambda}{\pi} \\
\frac{1}{2} \\
\frac{1}{2}\end{array}$ & $\begin{array}{l}\text { 忞 } \\
\mathbf{\lambda} \\
\underline{\mathbf{z}}\end{array}$ & 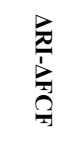 & 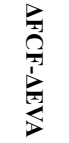 & 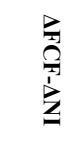 & 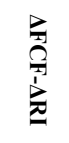 \\
\hline 0.12 & 0.140 & 0.120 & 0.000 & 0.010 & 0.000 & 0.010 & -0.001 & -0.001 & $0 / 00$ & -0.001 & 0.009 \\
\hline
\end{tabular}

significant at the 5 percent level

There are 10 regression models that four first models of them are one variable regressions and the rest of them are two variable regressions. The dependent variable is current stock return and the independent variables are changes in economic value added $(\Delta$ EVA), changes in net income $(\Delta \mathrm{NI})$, changes in residual income $(\Delta \mathrm{RI})$ and changes in free cash flow $(\Delta \mathrm{FCF})$.

Hypothesis 3: Results of the investigating hypothesis 3 are presented in table 4. Part A shows data such as Estimated Coefficient, $\mathrm{t}$-statistics, Standard Errors, F-statistic and adjusted $\mathrm{R}^{2}$ related to each models. Every four proceeding models contain one variable regression for each independent variable (EVA, NI, RI and FCF) and the Next 6 models include the multiple regressions for paired variables. In every one variable regression, all independent variables have a negative relationship with the future stock return except EVA. Minimum Standard Errors for all one variable regressions belong to FCF again. In pairwise regressions there is also positive relationship between EVA and the stock return in all situations.

Part $\mathrm{B}$ in table 4 exhibit the degree of relative information content for each independent variable. The greatest relative information content belongs to FCF (0.08), RI (0.06), EVA (0.059) and NI (0.058), respectively. As shown, FCF slightly surpasses other measures in relative information content with the future stock return. As result, our claim that EVA has the largest relative information content with future the stock return, are rejected. In contrast, in a study that is close to our research, Machuga et al. (2002) documented that EVA has the greatest ability for 
predicting EPS among other measures such as net income and cash flows. Our results show that none of the variables have high ability of predicting the stock return.

Part $\mathrm{C}$ in table 4 reveals the results of incremental information content. As shown in table 4, all variables have relatively the same degree of incremental information content. Only FCF slightly takes advantage of greater incremental information content. It means that Hypothesis 3(B) is rejected too.in other words, EVA has not the largest incremental information content with the future stock return among other measures.

Table 4. This table contains data about regression models

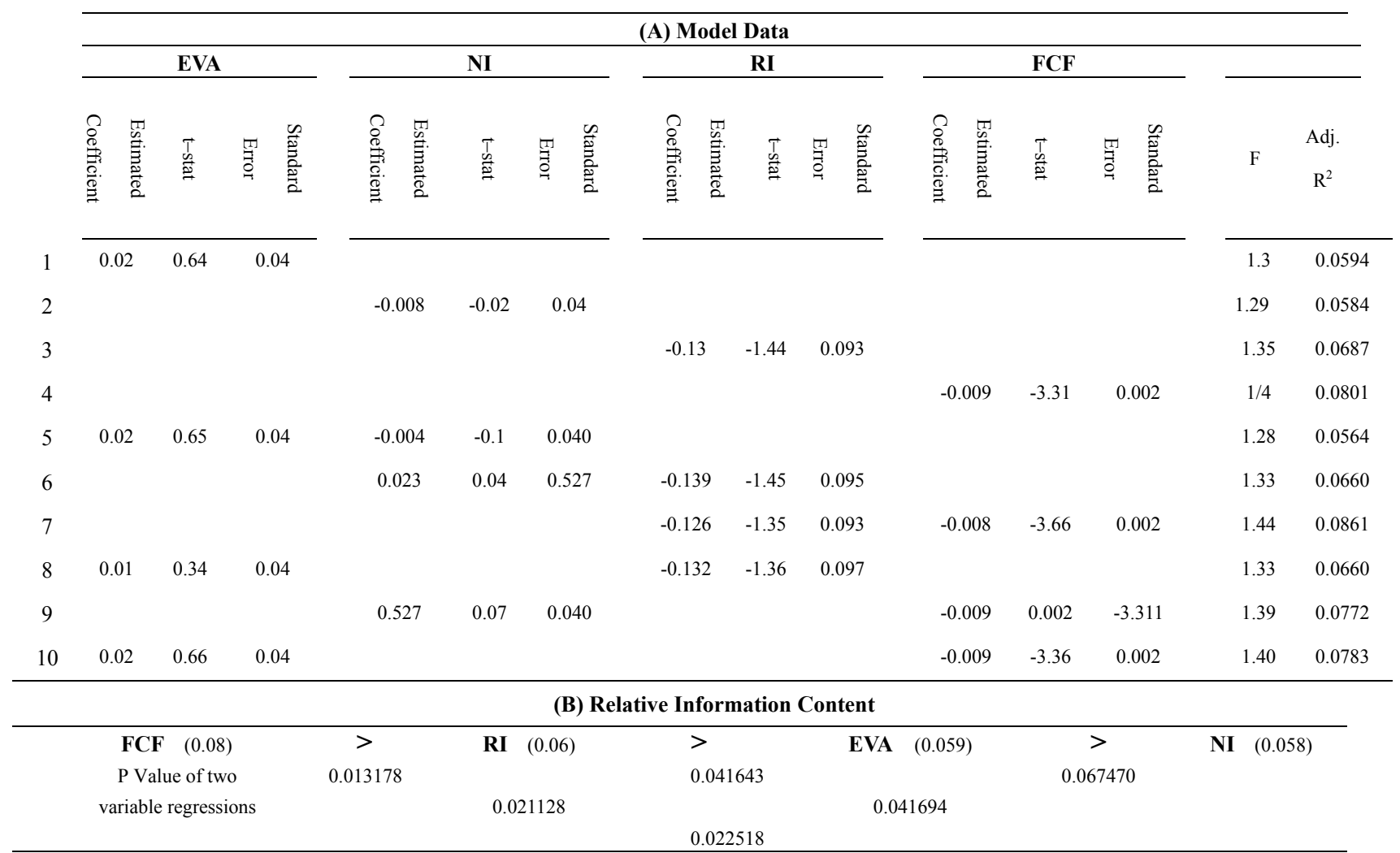

(C) Incremental Information Content

\begin{tabular}{|c|c|c|c|c|c|c|c|c|c|c|c|}
\hline $\begin{array}{l}\text { Ty } \\
2 \\
\text { 2 } \\
\underline{2}\end{array}$ & 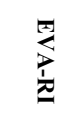 & 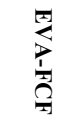 & $\frac{3}{\frac{2}{x}}$ & $\underset{\frac{Z}{2}}{\underline{z}}$ & $\begin{array}{l}\frac{Z}{1} \\
\frac{1}{2} \\
\underline{2}\end{array}$ & $\begin{array}{l}\frac{\pi}{1} \\
\frac{\pi}{2} \\
>\end{array}$ & $\begin{array}{l}\boldsymbol{z} \\
\underline{\mathbf{Z}}\end{array}$ & $\begin{array}{l}\frac{\pi}{\pi} \\
\frac{\pi}{\pi} \\
\hat{T}\end{array}$ & 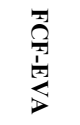 & $\begin{array}{l}\vec{x} \\
\hat{A} \\
\underline{1} \\
\underline{1}\end{array}$ & 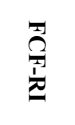 \\
\hline-0.001 & -0.002 & -0.001 & -0.003 & -0.002 & -0.002 & 0.007 & 0.007 & 0.006 & 0.018 & 0.018 & 0.017 \\
\hline
\end{tabular}

significant at the 5 percent level

There are 10 regression models that four first models of them are one variable regressions and the rest of them are two variable regressions. The dependent variable is stock return of year $(\mathrm{t}+1)$ and the independent variables are economic value added (EVA), net income (NI), residual income (RI) and free cash flow (FCF). 
Table 5. This table contains data about regression models

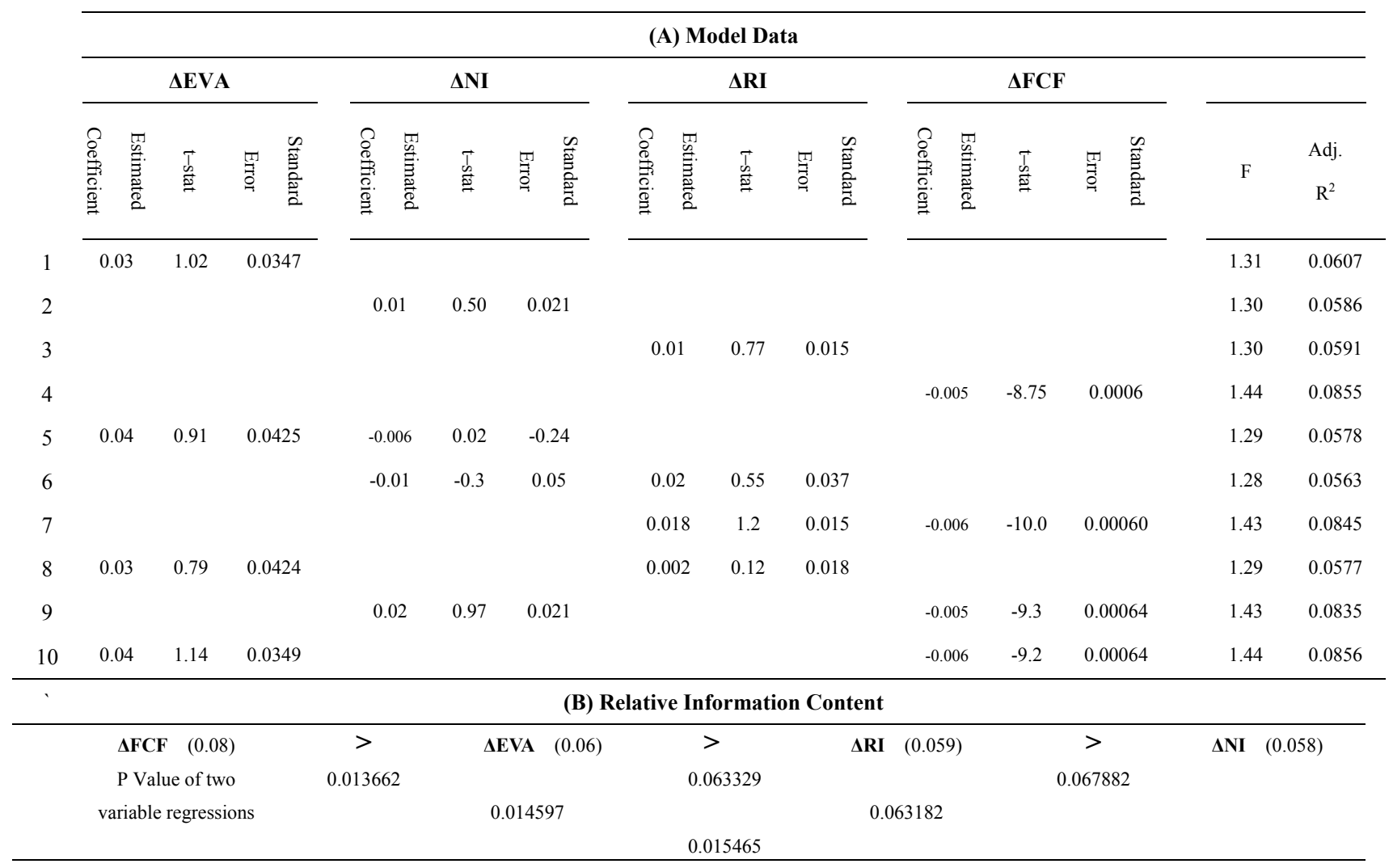

(C) Incremental Information Content

\begin{tabular}{|c|c|c|c|c|c|c|c|c|c|c|c|}
\hline 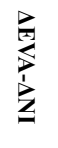 & 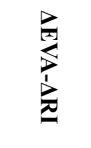 & 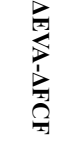 & 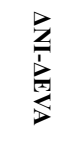 & 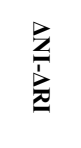 & 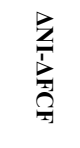 & 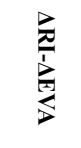 & 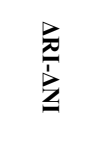 & 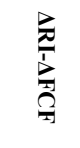 & 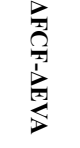 & $\begin{array}{l}\mathbf{R} \\
\hat{3} \\
\mathbf{f}_{1}^{1} \\
\underline{\mathbf{z}}\end{array}$ & 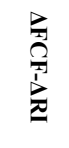 \\
\hline-0.0 & -0.001 & 0.000 & -0.002 & -0.002 & -0.002 & -0.00 & -0.002 & -0.001 & 0.024 & 0.0249 & 0.025 \\
\hline
\end{tabular}

significant at the 5 percent level

There are 10 regression models that four first models of them are one variable regressions and the rest of them are two variable regressions. The dependent variable is stock return of year $(t+1)$ and the independent variables are changes in economic value added $(\triangle \mathrm{EVA})$, changes in net income $(\Delta \mathrm{NI})$, changes in residual income $(\triangle \mathrm{RI})$ and changes in free cash flow $(\Delta \mathrm{FCF})$.

Hypothesis 4: Results of the investigating hypothesis 4 are exhibited in table 5. Part A shows Estimated Coefficient, $\mathrm{t}$-statistics and Standard Errors related to each models. Four first models include one variable regressions for each independent variable $(\triangle \mathrm{EVA}, \Delta \mathrm{NI}, \triangle \mathrm{RI}$ and $\triangle \mathrm{FCF})$ and the next 6 models include the multiple regressions for paired independent variables. In right side of table 3, F-statistic and adjusted R2 of models are shown. In every one variable regression, all independent variables have a positive relationship with the future stock return except $\triangle \mathrm{FCF}$. The greatest Estimated Coefficient is belonged to $\triangle \mathrm{EVA}$, but generally all the variables have low amounts of Estimated Coefficient. Minimum Standard Errors for all one variable regressions are belonged to $\triangle \mathrm{FCF}$. In pairwise regressions, there are positive relationship between $\triangle \mathrm{EVA}$ and $\triangle \mathrm{RI}$, and the future stock return in all situations.

Part $\mathrm{B}$ in table 5 exhibits the results of relative information content for each independent variable. The greatest relative information content is related to $\triangle \mathrm{FCF}(0.08), \triangle \mathrm{EVA}(0.06), \Delta \mathrm{RI}(0.059)$ and $\Delta \mathrm{RI}(0.058)$, respectively. All variables have relatively the same degree of relative information content. Only $\triangle \mathrm{FCF}$ slightly takes advantage of greater relative information content. As result, our claim that $\triangle$ EVA have the largest relative information content with the future stock return, are rejected. 
Part $\mathrm{C}$ in table 5 shows the results of incremental information content. According to table 3 , the incremental information content of all variables is close to zero, but $\triangle \mathrm{FCF}$ has the greatest degree of incremental information content among others. This result shows that Hypothesis 4 (B) is rejected.it means that $\triangle$ EVA does not have the largest incremental information content with the future stock return among others.

\section{Conclusions}

There are many researches that examined the relationship between EVA and the stock return that show the superiority of EVA for evaluating the firm's performance among other measures, e.g. (Uyemura et al. 1996, Lehn and Makhija (1996)). Some papers also reported that EVA has a high power of predictability among others, e.g. (Machuga et al. (2002) and Movassagh et al. (2011)). Current research examines the main performance measures (Net income (NI), residual income (RI), economic value added (EVA) \& free cash flow (FCF)) of firm and management to find out whether EVA has a high power of explaining among other measure or not. For this pupose, we apply measures' relevant information content as well as incremental information content. Pooled regression method is employed for testing the hypothesis. Moreover, our investigation is based on main variables (EVA, NI, $\mathrm{RI}$ and FCF) and their changes ( $\triangle \mathrm{EVA}, \triangle \mathrm{NI}, \triangle \mathrm{RI}$ and $\triangle \mathrm{FCF}$ ). Our results support the claims made by Stewart (1993) that EVA is a better measure to explain the stock returns among other accounting based performance measures. Furthermore, by comparing different performance measures this research concludes that $\triangle \mathrm{EVA}$ has both the largest relative information content and the largest incremental information content with the current stock return. Worthington and West (2004) reached similar conclusions.

This research also examine the predictability of EVA among other measures and results of this investigation reveal that neither EVA nor $\triangle \mathrm{EVA}$ have the largest relative information content or the largest incremental information content with the future stock return. Only FCF and $\triangle \mathrm{FCF}$ slightly take advantage of them.

\section{References}

Anthony, R. (1973). Accounting for the Cost of Equity. Harvard Business Review, 51, 88-102.

ArabSalehi, M., \& Mahmoodi, I. (2011). EVA® or Traditional Accounting Measures; Empirical Evidence from Iran. International Research Journal of Finance and Economics, 65.

Baltagi, B. H. (2008). Econometrics (5th ed.), springer

Biddle, G. C., Bowen, R. M., \& Wallace, J. S. (1997). Does EVA beat earnings? Evidence on associations with stock returns and firm values. Journal of Accounting and Economics, 24, 301-36. http://dx.doi.org/10.1016/S0165-4101(98)00010-X

Chen, S., \& Dodd, J. L. (1996). EVA: A New Panacea?. Business and Economic Review, 42(4), 26-28.

Chen, S., \& Dodd, J. L. (2001). Operating Income, Residual Income and EVA(TM): Which Metric Is More Value Relevant?. Journal of Managerial Issues, 13(1), 65-87.

Dearden, J. (1972). How to make incentive plans work. Harvard Business Review, 50, 117-122.

Desai, A. M., \& Ferri, F. (2006). Understanding Economic Value Added. Retrieved from: http://harvardbusinessonline.hbsp.harvard.edu/bo2/en/comman/item_detail.jhtml?id=206016.

Fabozzi, F. J., \& Peterson, P. P. (2003). Financial Management and Analysis (2nd ed.). John Wiley \& Sons, Inc

Fernandez, P. (2003). EVA, economic profit and cash value added do not measure shareholder value creation. Journal of Applied Finance, 9(3), 74-94.

Fingan, M. (1991). Extension of the EVA and MVA applications. Financial Analysts Journal, 1(1), 554-556.

Fiordelisi, F. (2007). Shareholder Value and the Clash in Performance Measurement. Are Banks Special?, Centre for Banking and Finance, U.K,University of Wales Bangor.

Fu, R., Leong, K., \& Zaima, K. J. (2011). Negative EVA And Value: A Paradox?. Journal of Academy of Business And Economics, 11, 128-138.

Haddad, S. F. (2012). The Relationship between Economic Value Added and Stock Returns: Evidence from Jordanian Banks. International Research Journal of Finance and Economics, 89.

Hall. (1998). Study of the relationship between MVA and EVA for south African companies. Journal of finance, 2(1), 26-38.

Hamilton, J., Rahman, S., \& Lee, C. A. (2009). EVA: Does Size Matter?. Review of Pacific Basin Financial Markets and Policies, 12(2), 267-287. http://dx.doi.org/10.1142/S0219091509001629 
Holiana, J. M., \& Reza, M. A. (2011). Firm and industry effects in accounting versus economic profit data. Applied Economics Letters, 18, 527-529. http://dx.doi.org/10.1080/13504851003761756

Jensen, M. (1986). Agency costs of free cash flow, corporate finance, and takeovers. American Economic Review, 76(2), 329-423.

Kramer, J. K., \& peters, J. R. (2001). An Interindustry analysis of Economic Value Added as a proxy for Market Value Added. Journal of Applied corporate finance, 1-15.

Lehn, K., \& Makhija, A. K. (1996). EVA and MVA: as performance measures and signals for strategic. Strategy and Leadership, 24, 34-38.

Machuga, S. M., Peeiffer, P. J., \&Verma, K. (2002). Economic Value Added, Future Accounting Earnings, and Financial Analysts' Earnings Per Share Forecasts. Review of Quantitative Finance and Accouting, 18, 59-73. http://dx.doi.org/10.1023/A:1013814328460

Movassagh, R., Seyyedi, M. H., \& Tahmasebi, M. R. (2011). Economic Value Added, Future Accounting Earnings, and Financial Analysts' Earnings per Share Forecasts. Interdisciplinary Journal of Contemporary Research in Business, 3(2).

O'Byrne, S. F. (1996). EVA and market value. Journal of Applied Corporate Finance, 9, 116-25. http://dx.doi.org/10.1111/j.1745-6622.1996.tb00109.x

Prakash, J. A., Chang, C., Davidson, L., \& ChenLee, C. (2003). Adoption of Economic Value Added and Firm Risk. The International Journal of Finance, 15(2).

Sharma, K. A., \& Kumar, S. (2010). Economic Value Added (EVA) - Literature Review and Relevant Issues. International Journal of Economics and Finance, 2(2).

Shrieves, E. R., \& Wachowicz, M. J. (2001). Free Cash Flow (FCF), Economic Value Added (EVA TM), And Net Present Value (NPV): A Reconciliation Of Variations Of Discounted-Cash-Flow (DCF) Valuation. The engineering economist, 46(1). http://dx.doi.org/10.1080/00137910108967561

Shubita, F. M. (2010). The Relationship between EVA and Stock Returns. International Research Journal of Finance and Economics, 59.

Stewart, G. B. (1991). The Quest For Value. Harper-Collins, New York.

Stewart, S. (1993). Comparison of Economic Value Added with popular accounting measures. Financial Analysts Journal, 2(2), 123-133.

Teker, D., Teker, S., \& Sonmez, M. (2011). Economic Value added Performances of Publicly Owned Banks:Evidence from Turkey. International Research Journal of Finance and Economics, 75, 132-137.

Tsuji, C. (2006). Does EVA beat earnings and cash flow in Japan?. Applied Financial Economics, 16, 1199-1216. http://dx.doi.org/10.1080/09603100500447537

Uyemura, D. G., Kantor, C. C., \& Petit, J. M. (1996). EVA for banks: Value creation, risk management and profitability measurement. Journal of Applied Corporate Finance, 9(2), 94-111. http://dx.doi.org/10.1111/j.1745-6622.1996.tb00118.x

Worthington, A., \& West, T. (2004). Australian Evidence Concerning the Information Content of Economic Value Added. Australian Journal of Management, 29(2), 201-242. http://dx.doi.org/10.1177/031289620402900204 